\title{
Records Keeping For Effective Administration of Secondary Schools
}

\author{
Amos Oyetunde Alabi \\ Emmanuel Alayande College of Education, Oyo, Oyo State, Nigeria \\ E-mail: amosalabi@yahoo.com
}

Received: April 20, 2017 Accepted: May 22, 2017 Online published: June 12, 2017

doi:10.5296/jpag.v7i2.11182 URL: https://doi.org/10.5296/ jpag.v7i2.11182

\begin{abstract}
This paper examined records keeping for effective administration of secondary schools. The types of records available in schools-statutory and non-statutory were identified, explained and listed. Many of those records were fully discussed pinpointing their relevance to the effectiveness of secondary school administration. Importance of keeping school records to all stakeholders of secondary school education and even beyond was well stated. The paper postulates that without keeping appropriate, adequate and relevant school records, there cannot be effective and efficient administration of secondary schools. Conditions for keeping and maintenance of school records were discussed. Certain problems about records keeping in secondary schools were highlighted and practical solutions to those problems were given. Records keeping are very central to effective administration of any secondary school.
\end{abstract}

Keywords: Secondary school, school records, effective secondary school administration, records keeping and maintenance, records keeping problems.

\section{Introduction}

School is one of the very most important establishments in human societies. The purpose for which the school is established can only be achieved through effective administration. There is no other way by which the school can achieve the purpose of its establishment other than effective administration. Effective administration therefore is that administration that helps to bring about optimum achievement of any organization/establishment and in this case, the school. One of the very most important aspects of school administration is record keeping. Record keeping is very important in school administration because it affects all other aspects of school administration such as planning, budgeting, staffing, facilities, discipline etc. And whether the school is primary, secondary or tertiary institution, keeping of records cannot be ignored for record keeping boosts the administrative effectiveness of such school and so, record keeping is not an exclusive of any level of education. This paper focuses records 
keeping for effective administration of secondary schools.

\section{What are School Records?}

Record, according to Longman Dictionary of Contemporary English is: (i) a written statement of facts, events, etc (ii) the known p[as of someone's past behavior]

(iii) anything that provides information about the past, etc.

From these definitions of the dictionary, one can safely say that school records are written statements of information (facts, events, etc) about a school's life. Tella (1991) defines school records as "the totality of documents, structures (of relatively permanent nature) that are of sentimental, economic or historical value to a particular school. On the other hand, Ajayi and Ayodele (2002) see school records as "pieces of information on relevant events about a school". These definitions corroborate the one given by the dictionary in one way or the other.

School records can therefore be defined/described as information keeping documents on school administration. They are at times referred to as the encyclopedia of school activities. Most of them are kept because Education Law of the country requires that they must be kept. Ozigi(1977) stressed that "Education law demands that every educational institution should keep certain school records". School records are also kept because of the useful information they provide about the students, teachers, the school and the educational system in general.

\section{Importance of Keeping School Records}

The significance of keeping records in a secondary school cannot be overemphasized. Apart from the importance of each record, there is a great value in the keeping of school records. Ozigi(1977), Salami, Alabi, and Okemakinde(2002), Okpetu and Peretomode(2004) and Paseda(2009) have all identified the importance of keeping school records. Some of the significance of school records keeping is:

a. It is an important aspect of (school) administration. It is compulsory and can never be jettisoned

b. It provides useful information on the progress and development made within the school

c. For providing information for parents and guardians who may seek information regarding the general conduct and academic performance of their children and wards at school

d. To enable the teacher know something about his students and through this be in a better position to assist them academically, morally, socially, etc in addition to being able to predict their behavior and provide needed information to whoever may need it.

e. For research purposes in education and in other fields

f. For planning and budgeting purposes 


\section{Ml Macrothink}

Journal of Public Administration and Governance ISSN 2161-7104 2017, Vol. 7, No. 2

g. To enable the school authority provide necessary data about the school which may be required from time to time from the proprietor / proprietress or other agencies of education

h. To enable the school authority provide requested information to employer of labor who may need the services of the students for job placement

i. To provide useful information about any student intending to further his/her education in a tertiary institution

j. For assessment of teachers and principals

k. To save the school from any unnecessary embarrassment as well as legal tussle

1. For the purpose of continuity in school administration

m. For effective and efficient management of the school

\section{Types of School Records}

There are two types of records that a secondary school can keep. These are statutory and non-statutory.

Statutory school records are those records that are mandatory or compulsory under the law to be kept by each school as such they are expected to be kept by all schools. Under the education law in Nigeria, the following are some of the statutory records to be kept in schools; Admission Register, Daily Attendance Register, Diary of Works, Log Book, Lesson Note or Plan, Time-Table, School Budget Record, Visitor's Book, Corporal Punishment Book, Continuous Assessment Book, Time Book, Testimonial and Transfer Certificate Book, National Policy on Education, Examination Records, etc.

Non-statutory records, on the other hand, are not mandatory to be kept but they are nevertheless equally important and useful for record purposes for the schools that can keep them. Such records if kept in schools usually help the principal and his management in the day-to-day administration of the school's affairs. Among such records are: Inventory Book, Stock Book, Requisition Book, Duty Roster Book, Movement Book, School Calendar, Staff Minutes Book, Staff Record, Physical Development Record, Health Record Book, Accounts Record, The Cash Book, Fees Register, Payment Voucher, Announcement Book, PTA Minutes Book, Record of Progress, Staff Union Minutes, Cooperative Society Record, etc. The list of the records is in exhaustive. The more the need for having an accurate keeping of necessary information on any area of administration of a secondary school, the more the necessity to create a record for such imperative areas.

Some of these records are hereby discussed briefly:

a. Admission Register: As its name is, the register shows the list of students admitted into the school on yearly basis and records those that exit from the school from time to time with reasons for doing so. The register indicates the name, age, address of each student enrolled each year and the date of the 
enrolment. Each student is given an admission number just as matriculation number in the tertiary institution though this is not as pronounced as the matriculation number in the secondary school. This record is kept by the principal of the school. It serves so many useful purposes such as authenticating the claim of any student of that school, tracing the progress of any student of the school, giving some personal details about the students, their parents and guardians etc.

b. Attendance Register: This is often qualifies or modifies by 'daily' to read Daily Attendance Register. This register is kept for each arm of classes within the school. It contains the names of students arranged in alphabetical order of surnames. Usually, boys' names are firstly arranged before the girls. The names of the female students are usually written with red ink. This register shows the daily attendance of each student in school. This record is kept and marked by the class/form teacher. It is marked twice a day; in the morning and in the afternoon the total weekly attendance of each pupil and of the whole class is made on Friday after which the record is passed to the principal or his designated vice for checking and signing. The teacher must sight every student he marks 'present'. On no account should he (the teacher) marks a student he has not sighted as 'present' in the class or school. This record is very helpful in discovering whether any student is in school or not in any particular date and time. It can also help in identifying sick students, truants, absentees and those students that attend school regularly.

c. The Log Book: This is a daily record of significant happenings and events in the life of a school. Events that are recorded in the log book include resumption and vacation for the term, sports and founder's day's activities, school excursions, changes of staff, examinations, names of important visitors and purpose(s) of visiting, PTA meetings, school routine inspection, etc. This book gives a summary of the historical development of the school. The record is absolutely kept and handled by the principal and it is out of bounds to other teachers. The book is at times referred to as "black book" and it is always kept under lock and key.

d. Syllabus/Curriculum: Each school must have the approved syllabus/curriculum which contains topics to be treated for each subject, for each class and for each year of the course. At the secondary school level the syllabus or curriculum is prepared by the Ministry of Education and the examining bodies such as West African Examination Council (WAEC) and National Examination Council (NECO). The syllabus/curriculum is usually kept in the office of the school principal or vice principal (academics).

e. Teachers' Record of Work (Diary): This is a record of work showing what area of the syllabus/curriculum in a subject a teacher has covered. The record is kept by each teacher and must be produced on demand. It is important that each 
teacher enters in the record all the topics taught in the subject weekly and submit to the principal through his head of department for checking, signature and date. This important record is very useful when a teacher is transferred and another teacher has to take over his job. The teacher taking over would not have problem in identifying at what point he should start his job.

f. Lesson Plan/Notes: Every subject teacher is expected to prepare his plan or notes of teaching on each subject for the class(es) he has daily. The notes are expected to be comprehensive enough to be understood by any other teacher in the same subject area to be able to use it to teach in case the teacher is officially engaged or indisposed that he cannot teach the subject. The lesson plan or notes are expected to be examined "marked" and approved by the head of department before it can be used by the teacher. The lesson plan is a mark of level of preparation by a teacher for his teaching hence it is expected that such a teacher should be able to deliver his teaching well.

g. The School Time-Table: This record shows the daily activities/routine of the school. The time-table shows the time the school opens daily, the time for morning devotion, recesses (short and long breaks) and closing time. It also shows the time a subject or a class is to hold; the teacher, the class and the classroom. The school time-table is usually displayed in the office of the principal or vice principal (academics), head of department's office, the staff room, on the notice board(s) and each teacher should be conversant with it or is expected to extract the time-table as it affects his teaching functions and other duties in the school.

h. Staff Record Book: This record contains the list of all the staff members in a school with their biographical data. It contains such information as when a teacher joins the staff of the school, his age, qualifications, experience, date of assumption of duty, date of resignation and transfer and the reason(s) for such.

i. Teachers' Time Book: This is filled by each teacher on daily basis. It shows how punctual and regular a teacher is in school. It is always kept in the school office where every teacher will see it, write his/her name, time he/she arrives school and append his/her signature. Also, at the close of the school or before the close of the school for the day, the teacher still has to indicate the time he/she is leaving the school. The principal or any of his designated vice has to check the time book at the end of the day and enter his remarks.

j. Visitors' Book: This is a book which every visitor that is on special duty or assignment to the school signs. Such visitors include officers from the Ministry of Education and other stakeholders. Names and addresses of such visitors are recorded in the book. Also, the record will contain date, time of visit and purpose of the visit. The visitor will put down his remarks about the school with regard to his impression about the school. The record is always in the custody of the school head. 
k. Staff Movement Book: This is a book in which any teacher going out of the school during the school hours enters his name, destination, the reason for going out and the time he is going. The time he returns is also indicated when he comes back. This serves as a control measure to reduce unauthorized movement of teachers during official hours of work.

1. Cash Book: This book shows the incomes and expenditures of the school. The book is prepared by the bursar on daily basis. School incomes that are recorded in the cash book include grant-in-aid, school levies, agricultural sales, gifts and donations to the school etc, while the school expenditures that are recorded in the book include stationeries, repairs and maintenance, transportation, utilities etc. The record indicates the financial management and ability of the school principal and the school as well.

m. Stock Book: This is the record of consumable and non-consumable goods in the school. The consumable goods are chalk, rulers, biros, dusters, etc, which are constantly used and mostly used off. The non-consumables consist of furniture and fittings, equipment, radio television sets, etc. The record should contain the date of purchases, quantity, type of article, date of issue and return. It is very useful when the principal wants to make a requisition for materials for the following year.

n. Punishment Book: This records all cases of punishment especially corporal ones administered to an offending student in the school. The record shows the name of the student, his class, age, sex, the offence committed, the punishment given, the date, the teacher who administered the punishment, any inquiry and the result of the punishment on the offender. The book protects the child from unreasonable punishment by the teachers. It also protects the teacher from unwarranted criticism by parents resulting from exaggeration of punishments by the students.

o. Staff Minutes Book: This records the minutes of staff meetings. Staff are expected to meet from time to time to take decisions on how they can be more productive and effective in the discharge of their duties. This record helps the teacher to know the future line of action and to follow same in line with the decision they had jointly taken together in the staff meeting.

p. Continuous Assessment Book: It contains a comprehensive information about each student's performance and progress in academics, sports, social activities, etc in the school. The new education policy emphasizes on the up-to-date keeping of pupil's continuous assessment which is used for very many purposes.

q. School Inventory: This is the record of major equipment and facilities in the school. Such facilities include, the buildings, furniture, vehicles, generating plants, mowers, tractors, etc. The date, the time, the value at the construction of 
the building or the purchase of the materials are recorded down. It helps in keeping track of the major facilities of the school. It also helps to monitor or indicate the depreciation of the facilities and equipment.

r. National Policy on Education: This is a must for every secondary school. It contains all necessary information about every level of education in Nigeria. Every secondary school teacher needs to know what the government's policy is on secondary school education so that they can fit in properly and contribute meaningfully to the system.

\section{Keeping and Maintenance of School Records}

Identifying and knowing the type of school records to be kept in school is theoretical, keeping and proper maintenance of such records is practical. As such, it is necessary to be practical rather than being theoretical since administration is practical. Therefore, there are certain conditions that should be met for keeping and proper maintenance of school records. Some authors (Oyedeji (1998) in Ajayi and Ayodele 2002), Oyewobi and Alabi (2002) identified the following as very important for keeping and maintenance of school records.

a. The records must be full and complete. They must contain total and whole information not bits or parts as bits or part information will lead to wrong decision and eventual falsehood.

b. They must be truthful and honest. School records must not contain lies. Those who fill the records must tell the truth. Decision and actions taken on lies will yield wrong results.

c. They must be available when needed. School records are not personal property of any teacher or even the principal to be kept at his home or be taken away from school just anyhow. They are properties of the school and must be kept in school always hence proper security must be provided for them.

d. They must be used to take appropriate actions. Each record has a purpose. As such appropriate record must be used to take appropriate decisions and actions. For example, in identifying the most punctual student, attendance register is the most appropriate record to consult. For some decisions and actions more than one record may be consulted.

e. They must be original. School records must contain what is going on in the school not just copying what was going in another school. This is why the school records are unique to each school because they present what are actual and facts as far as each school are concerned. School records are not imagined or fictionalized; they are records of realities on ground in the school.

f. They must be kept safe from excessive humidity and heat that can spoil them. They must be kept in good conditions for many generations to see and read. Adequate security must be provided for school records so that they can be easily retrieved in good and perfect conditions at any time. 


\section{Macrothink \\ Journal of Public Administration and Governance \\ ISSN 2161-7104 \\ 2017, Vol. 7, No. 2}

\section{Problems of Records Keeping in Schools}

There are certain problems of records keeping in schools. Ajayi and Ayodele (2002) have identified such as:

a. Lack of uniformity of record keeping

b. Apathy/laziness on the part of teachers to supply information or record information

c. Lack of formal training/induction of teachers in record keeping

d. Lack of continuity of records

e. Security problems - destruction of records

f. Fictitious/false information

g. Inadequate record keeping materials

Other problems in addition to the ones given above are: poor handling of records by the teachers and the use of prefects (students) to record in the school records. All the above identified problems can be solved jointly by the government, the principals and the teachers. The government should provide adequate records/materials for records with record keeping safety devices/equipment. Government should also provide training and re-training opportunities for principals and teachers in the management of school records. On the other hand, the principal and teachers should appreciate the need and importance of records in effective and efficient school administration. In addition, they should also develop good orientation and right attitude towards school records keeping and further be practical in keeping and maintenance of school records as presented in this paper.

\section{Conclusion}

Record keeping in secondary school is not optional. It is a must. It is mandatory and obligatory because without it there cannot be effectiveness in the administration of the school. The onus is therefore on the principal to see to the availability of adequate records, proper keeping and maintenance of those records in the school. Records' keeping is for yesterday, today and tomorrow.

\section{References}

Ajayi, I. A., \& Ayodele, J. B. (2002). Fundamentals of Educational Management. Ado-Ekiti: Greenline Publishers.

Okpetu, S. A., \& Peretomode, O. (2004). "School Records in Educational Administration" in V. F. Peretomode(ed) Introduction to Educational Administration, Planning and Supervision. Nigeria, Lagos: Joja Educational Research and publishers Ltd pp. 57 - 70.

Oyewobi, G. O., \& Alabi, A. O. (2002). Primary School Administration and Supervision (Revised) Ibadan: Falola Commercial Publishers. 


\section{Macrothink}

Journal of Public Administration and Governance ISSN 2161-7104 2017, Vol. 7, No. 2

Ozigi, A. O. (1977). A handbook on School Administration and Management. London: Macmillian Educational Limited.

Paseda, J. A. (2009). "School Records" in K. Oyesiku, S. Ogunsaju and J. Oni(ed). Contemporary School Administration in Nigeria. Nigeria: Tai Solarin University of Education pp. 136 - 150.

Pearson Education Limited. (2007). Longman Dictionary of Contemporary English: The Living Dictionary. England: London.

Salami, K. A., Alabi, A. O., \& Okemakinde, T. (2002). Basic Text on Educational Administration, Planning and Supervision. Oyo: Immaculate-City Publishers.

Tella, P. O. (1991). "School Records" in P. O. Tella, T. O. Awoyele, R. A. Alani(ed). Introduction to Administration in Education. Nigeria, Ikeja: Basic Books Publishers pp. $103-115$.

\section{Copyright Disclaimer}

Copyright for this article is retained by the author(s), with first publication rights granted to the journal.

This is an open-access article distributed under the terms and conditions of the Creative Commons Attribution license (http://creativecommons.org/licenses/by/4.0/). 